\title{
Novel Platinum(II) Complexes of Long Chain Aliphatic Diamine Ligands with Oxalato as the Leaving Group. Comparative Cytotoxic Activity Relative to Chloride Precursors
}

\author{
Heveline Silva, ${ }^{a}$ Carolina V. Barra,${ }^{a}$ Fillipe V. Rocha, ${ }^{a}$ Frederic Frézard, ${ }^{b}$ \\ Miriam T. P. Lopes ${ }^{c}$ and Ana Paula S. Fontes $*$, \\ ${ }^{a}$ Departamento de Química, Universidade Federal de Juiz de Fora, \\ 36036-900 Juiz de Fora-MG, Brazil \\ ${ }^{b}$ Departamento de Fisiologia e Biofísica and ${ }^{c}$ Departamento de Farmacologia, \\ Universidade Federal de Minas Gerais, 31270-901 Belo Horizonte-MG, Brazil
}

\begin{abstract}
Os complexos de platina são importantes no desenvolvimento de drogas anticancerígenas. Sua citotoxicidade pode ser afetada pelos ligantes abandonadores, devido ao mecanismo da reação de hidrólise que ocorre antes da ligação do complexo ao DNA. Os grupos não-abandonadores, como as diaminas lipofílicas, também podem afetar a velocidade de entrada do composto na célula. Neste trabalho é descrita a síntese de novos complexos de platina(II) contendo ligantes oxalato e derivados de etilenodiamina $N$-substituída por uma cadeia carbônica longa de tamanho variável. Os produtos foram caracterizados por análise elementar, espectroscopia de absorção na região do infravermelho e ressonância magnética nuclear de ${ }^{1} \mathrm{H},{ }^{13} \mathrm{C} \mathrm{e}{ }^{195} \mathrm{Pt}$. A atividade biológica dos complexos foi investigada em linhagens de células tumorais $\left(\mathrm{A}_{549}, \mathrm{~B} 16-\mathrm{F} 1, \mathrm{~B} 16-\mathrm{F} 10\right.$, MDAMB-231) e não-tumorais (BHK-21 e CHO). O tamanho da cadeia carbônica afetou a citotoxicidade e os complexos com oxalato mostraram-se menos citotóxicos do que os análogos com cloretos.
\end{abstract}

Platinum complexes play an important role in the development of anticancer drugs. Their cytotoxicity can be influenced by the nature of the leaving ligands, due to the hydrolysis reaction that occurs prior to the binding of the platinum complex to DNA. Also, non-leaving groups such as lipophilic diamines may affect cellular uptake. In this work, we describe the synthesis of platinum(II) complexes having oxalato and long chain aliphatic $N$-alkyl ethylenediamines as ligands. The products were characterized by elemental analyses, infrared spectroscopy and ${ }^{1} \mathrm{H}$, ${ }^{13} \mathrm{C}$ and ${ }^{195} \mathrm{Pt}$ NMR spectroscopy. Biological activity was assessed against tumor cell lines $\left(\mathrm{A}_{549}\right.$, B16-F1, B16-F10, MDA-MB-231) and non-tumor cell lines (BHK-21 and CHO). The length of the carbon chain affects the cytotoxicity and the oxalato complexes were less cytotoxic than the respective chloride-containing analogues.

Keywords: ethylenediamine, oxalato, platinum complexes, antitumor agents

\section{Introduction}

Cisplatin and carboplatin are widely used anticancer drugs for the treatment of testicular, ovarian, head, neck and non-small-cell lung cancer. ${ }^{1-3}$ However, their clinical usefulness has frequently been limited by severe side effects, such as nephrotoxicity, ototoxicity and neurotoxicity, and by the emergence of cancer cells resistant to cisplatin. ${ }^{4-6}$

Carboplatin was designed to overcome the severe side effects of cisplatin, and, indeed, the replacement

\footnotetext{
*e-mail: ana.fontes@ufjf.edu.br
}

of the labile chloride ligands by a comparatively more stable bidentate O-O leaving group resulted in a modified pharmacodynamic behavior and a more tolerable toxicological profile. ${ }^{7}$ However, the cross-resistance between cisplatin and carboplatin makes them both ineffective in the treatment of patients who fail to respond to therapy.

Over the last decades, many other platinum drugs have been developed in an attempt to improve the toxicity profile and, in particular, to obtain a drug that is able to overcome resistance. One of these third-generation drugs is oxaliplatin, $R, R$-1,2-diaminocyclohexane(O-O-oxalato) 
platinum(II), which has shown a wide and markedly different spectrum of activity and, more importantly, no cross-resistance to cisplatin and carboplatin. The non-hydrolyzable dach ligand makes the complex less polar, which has been proposed to contribute to a better cellular uptake. ${ }^{8,9}$ Platinum-DNA adducts, which are formed following uptake of the drug into the nucleus of cells, activate several cellular processes that mediate the cytotoxicity of these platinum drugs. ${ }^{10}$

Leaving groups, such as chloride in cisplatin and oxalato in oxaliplatin, can modify both the kinetics of hydrolysis and the reactivity of the drug. Non-leaving groups can confer different characteristics to platinum compounds, improving their cytotoxic activity by modifying cellular uptake and the way the complex interacts with DNA. ${ }^{11}$ Amphiphilic diamines with a long, $N$-alkyl chain may present surfactant properties. This feature can increase the affinity of the compounds for the cell membrane and thus facilitate their cellular uptake. ${ }^{12}$

Our research group has already investigated platinum complexes derived from long chain aliphatic diamines. It has been shown that the length of the carbon chain affects cytotoxity and cellular uptake of the chloride complexes. ${ }^{13}$ The impact of a different leaving group (oxalato) on the cytotoxic activity of the products was investigated in the present work using several cell lines such as breast and lung cancer cells. The toxicity of the complexes was also assessed in non-tumor cell lines such as kidney cells (BHK-21), which allowed us to examine a possible decrease in nephrotoxicity.

\section{Results and Discussion}

\section{Chemistry}

The platinum complexes with chloride and ethylenediamine derivatives $(\mathbf{1}, \mathbf{2}, \mathbf{3}$ and $\mathbf{4})$ were prepared by a procedure analogous to that reported earlier by our research group for the propanodiamine derivatives..$^{13,14}$ The platinum complexes with oxalato $(\mathbf{5}, \mathbf{6}, \mathbf{7}$ and $\mathbf{8})$, in their turn, were obtained from the chloride precursors (Scheme 1) using an extension of Dhara`s method. ${ }^{15}$ In this case, the reaction with silver nitrate was performed first and the resulting insoluble silver chloride was filtered off. Then, sodium oxalate was added to produce the desired complexes. Considering that the substituted nitrogen of the diamine is pro-chiral, the products are enantiomeric mixtures and no attempt was made to separate them.

For all complexes, the IR spectra (Table 1) show absorptions corresponding to $\mathrm{v}(\mathrm{N}-\mathrm{H})$ at $3200-3100 \mathrm{~cm}^{-1}$ and $v(\mathrm{C}-\mathrm{H})$ around $2920 \mathrm{~cm}^{-1}$. The IR spectra of the chloride compounds show absorptions corresponding to $v(\mathrm{Pt}-\mathrm{Cl})$ around $320 \mathrm{~cm}^{-1}$, characteristic of cis platinum compounds. For the oxalato complexes, the disappearance of the absorption due to $v(\mathrm{Pt}-\mathrm{Cl})$ at $320 \mathrm{~cm}^{-1}$ is noticeable, as well as the appearance of absorptions for $\mathrm{v}(\mathrm{Pt}-\mathrm{O})$ around $550 \mathrm{~cm}^{-1}$ (Figure 1). Other bands were recorded at 1670 and $810 \mathrm{~cm}^{-1}$ and were assigned to $\mathrm{v}(\mathrm{C}=\mathrm{O})$ and $v(\mathrm{C}-\mathrm{C}=\mathrm{O})$, respectively.

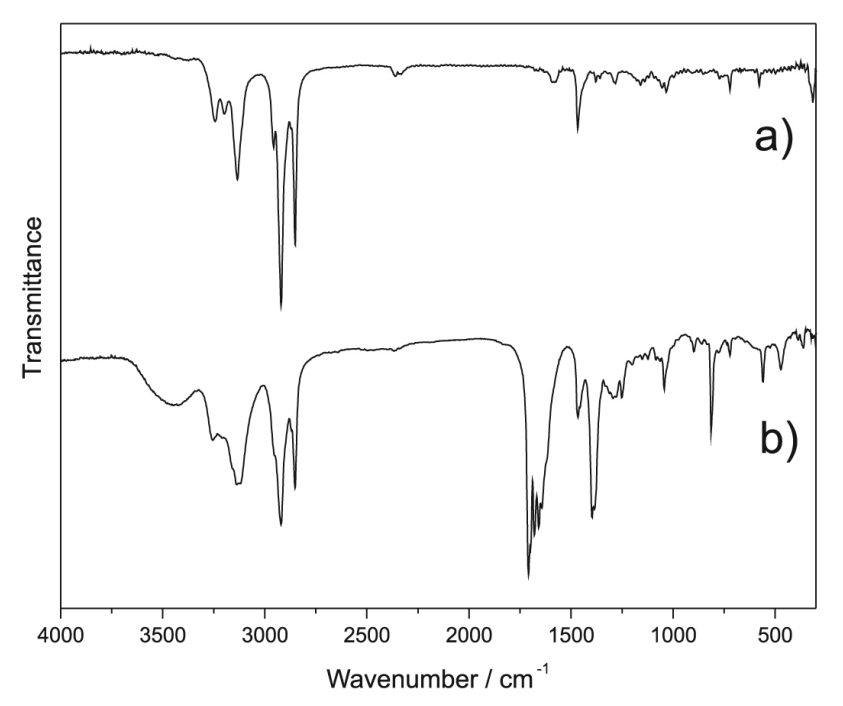

Figure 1. IR spectra: (a) Complex 1; (b) Complex 5.

NMR spectra were acquired using dmso- $d_{6}$ as the solvent. The chemical shifts are shown in Table 2.

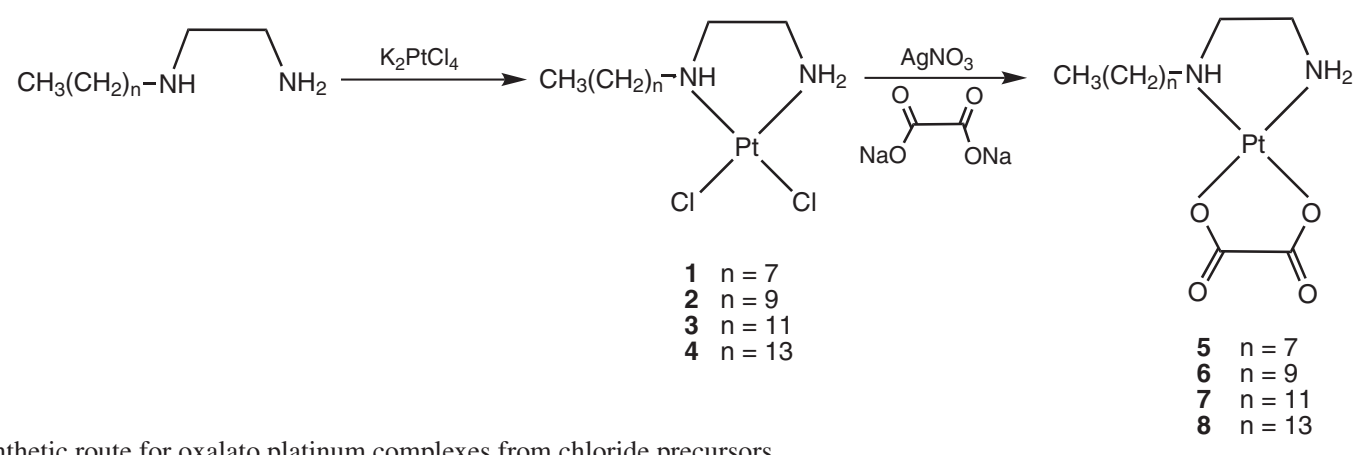

Scheme 1. Synthetic route for oxalato platinum complexes from chloride precursors. 
Table 1. Main IR absorptions $\left(\mathrm{cm}^{-1}\right)$

\begin{tabular}{lcccccccc}
\hline & \multicolumn{7}{c}{ Complexes } \\
\cline { 2 - 8 } & $\mathbf{1}$ & $\mathbf{2}$ & $\mathbf{3}$ & $\mathbf{4}$ & $\mathbf{5}$ & $\mathbf{6}$ & $\mathbf{7}$ & $\mathbf{8}$ \\
\hline $\mathrm{N}-\mathrm{H}$ & 3187 & 3134 & 3134 & 3134 & 3131 & 3128 & 3137 & 3136 \\
$\mathrm{C}-\mathrm{H}$ & 2927 & 2922 & 2920 & 2920 & 2923 & 2919 & 2918 & 2917 \\
$\mathrm{C}=\mathrm{O}$ & - & - & - & - & 1671 & 1679 & 1679 & 1678 \\
$\mathrm{C}-\mathrm{C}=\mathrm{O}$ & - & - & - & - & 806 & 814 & 813 & 813 \\
$\mathrm{Pt}-\mathrm{O}$ & - & - & - & - & 553 & 559 & 559 & 558 \\
$\mathrm{Pt}-\mathrm{Cl}$ & 318 & 321 & 322 & 315 & - & - & - & - \\
& 316 & 318 & 321 & 313 & & & & \\
\hline
\end{tabular}

Table 2. ${ }^{1} \mathrm{H}$ and ${ }^{13} \mathrm{C}$ NMR data (ppm); solvent: dmso- $d_{6}$

\begin{tabular}{|c|c|c|c|c|c|c|c|c|c|}
\hline & & \multicolumn{8}{|c|}{ Complexes } \\
\hline & & 1 & 2 & 3 & 4 & 5 & 6 & 7 & 8 \\
\hline \multirow[t]{10}{*}{${ }^{1} \mathrm{H}$} & $3 \mathrm{H}\left(\mathrm{CH}_{3}\right)$ & 0.84 & 0.84 & 0.86 & 0.84 & 0.84 & 0.85 & 0.85 & 0.84 \\
\hline & $\mathrm{H}\left(\mathrm{CH}_{2}\right)$ & 1.23 & 1.23 & 1.25 & 1.23 & 1.24 & 1.24 & 1.23 & 1.23 \\
\hline & $2 \mathrm{H} \underline{\mathrm{CH}}_{2}-\mathrm{CH}_{2}-\mathrm{NH}$ & 1.46 & 1.45 & 1.47 & 1.47 & 1.54 & 1.56 & 1.54 & 1.55 \\
\hline & & 1.75 & 1.74 & 1.76 & 1.74 & 1.67 & 1.68 & 1.69 & 1.68 \\
\hline & $2 \mathrm{H} \mathrm{CH}-\mathrm{NH}_{2}$ & 2.27 & 2.27 & 2.29 & 2.27 & 2.19 & 2.20 & 2.20 & 2.38 \\
\hline & $4 \mathrm{H} \underline{\mathrm{CH}}_{2}-\mathrm{NH}$ & 2.71 & 2.71 & 2.74 & 2.71 & 2.65 & 2.67 & 2.67 & 2.66 \\
\hline & & 2.82 & 2.82 & 2.84 & 2.82 & & & & \\
\hline & $\mathrm{NH}_{2}$ & 5.29 & 5.29 & 5.31 & 5.29 & 5.63 & 5.64 & 5.65 & 5.61 \\
\hline & & 5.37 & 5.35 & 5.38 & 5.36 & 5.88 & 5.89 & 5.89 & 5.88 \\
\hline & $\mathrm{NH}$ & 6.19 & 6.19 & 6.20 & 6.19 & 6.52 & 6.50 & 6.52 & 6.48 \\
\hline \multirow[t]{7}{*}{${ }^{13} \mathrm{C}$} & $\mathrm{CH}_{3}$ & 14.3 & 13.9 & 13.6 & 13.9 & 13.9 & 13.9 & 13.9 & 13.9 \\
\hline & $\mathrm{CH}_{2}$ & 22.4 to 31.5 & 22.1 to 31.3 & 21.7 to 30.9 & 22.1 to 31.2 & 22.1 to 31.2 & 22.1 to 31.3 & 22.1 to 31.3 & 22.1 to 31.2 \\
\hline & $\mathrm{CH}_{2}-\mathrm{NH}_{2}$ & 46.9 & 46.6 & 46.2 & 46.6 & 46.1 & 46.1 & 46.1 & 46.1 \\
\hline & $\mathrm{CH}_{2}-\mathrm{NH}$ & 52.3 & 52.0 & 51.6 & 52.0 & 53.4 & 53.5 & 53.3 & 53.3 \\
\hline & & 55.4 & 55.1 & 54.7 & 55.0 & 55.0 & 55.0 & 55.0 & 54.9 \\
\hline & $\mathrm{COO}^{-}$ & - & - & - & - & 165.6 & 165.6 & 165.6 & 165.6 \\
\hline & & & & & & 166.2 & 166.2 & 166.2 & 166.1 \\
\hline
\end{tabular}

In the ${ }^{1} \mathrm{H}$ NMR spectra of the diamines, signals around $\delta 0.9\left(\mathrm{CH}_{3}\right)$ as a triplet, $1.2\left(\mathrm{CH}_{2}\right), 2.6\left(\mathrm{CH}_{2}-\mathrm{NH}\right)$ and $2.8\left(\underline{\mathrm{CH}}_{2}-\mathrm{NH}_{2}\right)$ as multiplets were observed. In the $\delta 1.4$ to 2.5 region, the signals corresponding to the $\mathrm{NH}_{2}$ and $\mathrm{NH}$ hydrogens could be seen as triplet resonances. In the ${ }^{1} \mathrm{H}$ NMR spectra of the complexes, a high frequency shift was observed for the signals relative to the $\mathrm{NH}$ and $\mathrm{NH}_{2}$ hydrogens. They appeared as three broad signals in the $\delta 5.2$ to 6.2 region for the chloride complexes and 5.6 to 6.5 for the oxalato analogues.

No significant difference was observed when the ${ }^{13} \mathrm{C}$ NMR spectra of the diamines was compared with the spectra of the complexes. Signals corresponding to the $\mathrm{CH}_{3}$ group occurred around $\delta 14$. In the $\delta$ 22-32 region, signals attributable to the carbons from the aliphatic chain were observed. The carbon atoms directly bound to $\mathrm{NH}_{2}$ and $\mathrm{NH}$ gave signals in the $\delta 40-50$ region. For the oxalato complexes, signals corresponding to the carboxylato carbon were observed around $\delta 166$.

The ${ }^{195} \mathrm{Pt}$ NMR spectra (Figure 2) for complexes 1-4 showed only one signal around $\delta-2350$, while for complexes 5-8 only one signal, around $\delta-2050$, was observed. These chemical shift values are in agreement with data reported for similar compounds in the literature. ${ }^{16-18} \mathrm{As}$ expected, a shift to high frequency was observed, caused by the replacement of the chloride by oxalato, which altered the coordination sphere around the platinum ion.

The results of elemental analysis obtained for the complexes are in good agreement with the calculated values.

\section{Cytotoxic activity}

To analyze the potential of the compounds as antitumor agents, their cytotoxicity was evaluated in comparison to cisplatin and carboplatin in a panel of four tumor cell lines: lung cancer $\left(\mathrm{A}_{549}\right)$, melanoma (B16-F1 and B16-F10) and breast adenocarcinoma (MDA-MB-231), Table 3. The complexes were also examined for their cytotoxic properties on two types of non-tumor cell lines, kidney (BHK-21) and ovarian (CHO). The $\mathrm{IC}_{50}$ values, calculated from the dose survival curves obtained after $120 \mathrm{~h}$ of drug exposure (MTT test), are shown in Table 3.19 


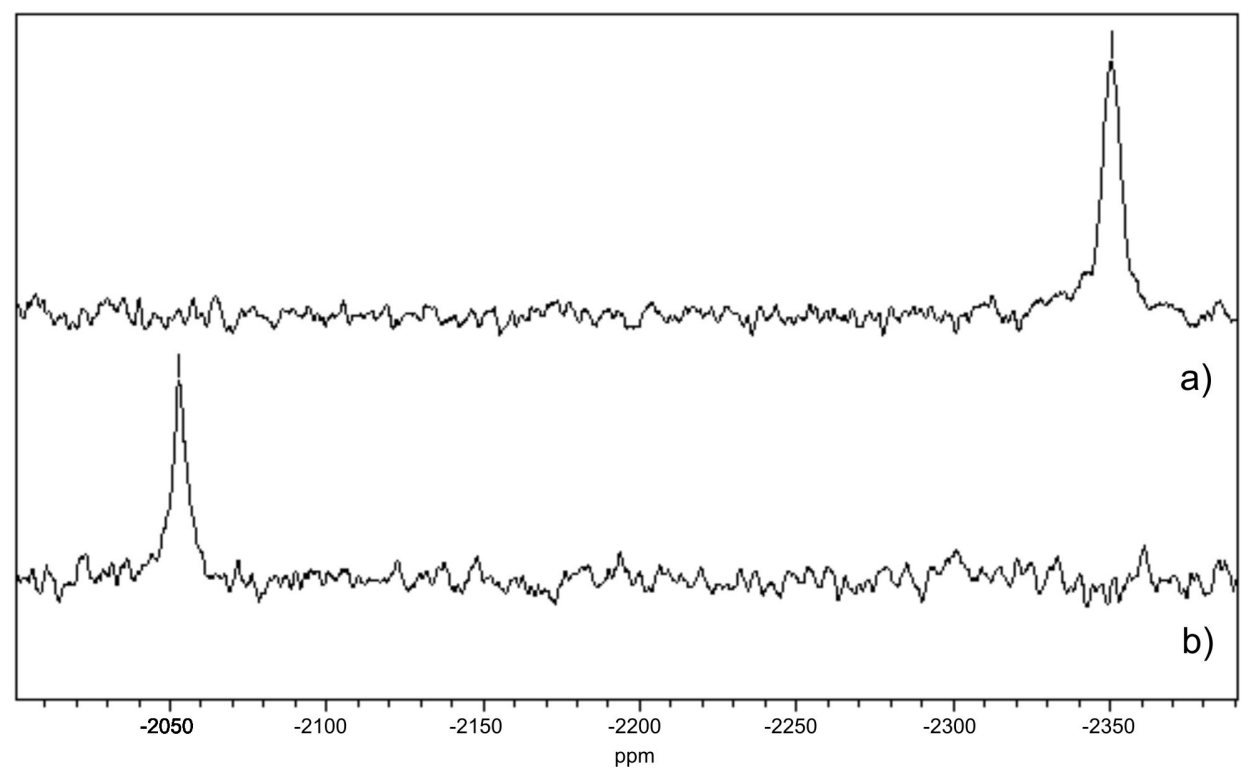

Figure 2. ${ }^{195} \mathrm{Pt}$ NMR spectra: (a) Complex 1; (b) Complex 5.

Table 3. $\log P$ and cytotoxic activities $\left(\mathrm{IC}_{50}\right)$ of the platinum complexes against tumor and non-tumor cell lines

\begin{tabular}{|c|c|c|c|c|c|c|c|}
\hline \multirow[b]{3}{*}{ Complex } & \multirow[b]{3}{*}{$\log \mathrm{P}$} & \multicolumn{6}{|c|}{$\mathrm{IC}_{50} * /\left(\mu \mathrm{mol} \mathrm{L}{ }^{-1} \pm\right.$ S.D. $)$} \\
\hline & & \multicolumn{4}{|c|}{ Tumor Cell Lines } & \multicolumn{2}{|c|}{ Non-tumor Cell Lines } \\
\hline & & $\mathrm{A}_{549}$ & MDA & B16-F1 & B16-F10 & BHK-21 & $\mathrm{CHO}$ \\
\hline 1 & 0.40 & $10.9 \pm 0.9$ & $28.8 \pm 2.0$ & $25.1 \pm 1.9$ & $6.3 \pm 0.5$ & $12.6 \pm 1.1$ & $25.1 \pm 2.3$ \\
\hline 2 & 1.31 & $16.6 \pm 1.5$ & $38.0 \pm 2.2$ & $9.5 \pm 0.8$ & $6.3 \pm 0.5$ & $19.1 \pm 2.0$ & $9.6 \pm 0.8$ \\
\hline 3 & 1.54 & $5.5 \pm 0.4$ & $16.6 \pm 1.2$ & $5.5 \pm 0.4$ & $4.2 \pm 0.3$ & $10.9 \pm 0.9$ & $2.6 \pm 0.2$ \\
\hline 4 & 1.56 & $12.6 \pm 1.0$ & $28.8 \pm 1.6$ & $12.6 \pm 0.8$ & $3.6 \pm 0.3$ & $5.5 \pm 0.4$ & $2.4 \pm 0.2$ \\
\hline 5 & & $60.6 \pm 2.0$ & $16.6 \pm 0.9$ & $21.9 \pm 1.6$ & $38.0 \pm 2.1$ & $16.6 \pm 1.4$ & $19.1 \pm 1.8$ \\
\hline 6 & & $33.1 \pm 1.5$ & $25.1 \pm 0.8$ & $19.1 \pm 1.5$ & $19.1 \pm 1.6$ & $16.6 \pm 1.3$ & $19.1 \pm 1.8$ \\
\hline 7 & & $12.6 \pm 0.8$ & $25.1 \pm 1.5$ & $14.5 \pm 1.4$ & $16.6 \pm 1.3$ & $16.6 \pm 1.4$ & $21.0 \pm 1.9$ \\
\hline 8 & & $13.5 \pm 0.7$ & $19.1 \pm 1.2$ & $14.5 \pm 1.2$ & $16.6 \pm 1.1$ & $11.0 \pm 1.0$ & $19.1 \pm 1.8$ \\
\hline Cisplatin & & $2.7 \pm 0.5$ & $1.4 \pm 0.2$ & $3.5 \pm 0.3$ & $4.2 \pm 0.2$ & $3.6 \pm 0.3$ & $5.5 \pm 0.4$ \\
\hline Carboplatin & & $20.1 \pm 0.9$ & $8.3 \pm 0.3$ & $6.3 \pm 0.6$ & $6.3 \pm 0.3$ & $50.6 \pm 2.0$ & $9.8 \pm 0.8$ \\
\hline
\end{tabular}

*Inhibitory concentration of $50 \%$ of cell growth. The values are the mean of triplicate determinations.

We observed that, in all cell lines assessed, the cytotoxicity was influenced by the leaving group, with oxalato complexes showing decreased activity compared to chloride precursors. Especially with the B16-F10 cell

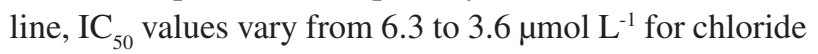
complexes (1-4) and from 38.0 to $16.6 \mu \mathrm{mol} \mathrm{L}^{-1}$ for the oxalato analogues (5-8). With the $\mathrm{A}_{549}$ cell line, while the $\mathrm{IC}_{50}$ value for chloride complexes is around $10 \mu \mathrm{mol} \mathrm{L}^{-1}$, those for the oxalatos vary from 60.6 to $13.5 \mu \mathrm{mol} \mathrm{L}^{-1}$.

The nature of the non-leaving group also affects cytotoxicity. The cytotoxic activity of the compounds in tumor cell lines exhibits an increasing trend with the increase of the carbon chain length when comparing complexes having 8,10 and 12 carbons in the alkyl moiety.
The analogues containing 14 carbons show less or similar activity. This structure/activity relationship is confirmed by $\log P$ values for the corresponding chloride complexes (Table 3), which were determined from the partition coefficients in $n$-octanol/water. This parameter is used to determine the lipophilic character of drugs: hydrophobic compounds will have a high $\log P$ value whereas hydrophilic compounds will have it low. We have found that as $\log P$ increases $\mathrm{IC}_{50}$ values decrease, i.e., increasing complex hydrophobicity increases cytotoxic activity. ${ }^{20,21}$ This correlation has been observed before by our group for similar platinum(II) complexes with ligands derived from 1,3-propanediamine; it can be explained based on the lipophilicity of the compounds..$^{13}$ The more lipophilic the 
compound is, the more rapidly it enters cells and the higher is its cytotoxic activity. The time the drug takes to enter the cells can explain why the chloride complexes were, in general, more cytotoxic than the corresponding oxalato complexes. Pereira-Maia and Garnier-Suillerot ${ }^{22}$ have shown that carboplatin is less toxic than cisplatin because carboplatin enters cells at a slower rate, and that may be what is occurring for the complexes reported herein. As another possible explanation, the rate of hydrolysis of the leaving group may differ between the chloride and oxalato complexes. Hydrolysis of the oxalato complexes requires initial ring-opening, ligand displacement by chloride and subsequent conversion to the aquo and/or hydroxy species, thus requiring more time to bind with the DNA bases. ${ }^{23,24}$

Cisplatin and carboplatin are more cytotoxic than the amphiphilic complexes, except when compared to carboplatin in $\mathrm{A}_{549}$ cell line, against which six of the amphiphilic complexes were more cytotoxic.

It is interesting to note that all the compounds exhibited lower cytotoxicity than cisplatin against non-tumor kidney cell (BHK-21), since nephrotoxicity is one of the most severe side effects caused by cisplatin. Also, compounds 1-4 were less toxic than cisplatin and carboplatin against non-tumor ovarian cell (CHO). A good alternative platinum drug to be used in cancer chemotherapy should be toxic in tumor cells and less aggressive in normal cells to avoid the various side effects.

\section{Experimental}

IR spectra were obtained on a Bomem FT IR MB-102 spectrometer in $\mathrm{KBr}$ pellets. ${ }^{1} \mathrm{H}$ NMR $(300 \mathrm{MHz}),{ }^{13} \mathrm{C}$ NMR (75 MHz) and ${ }^{195} \mathrm{Pt}$ NMR (64 MHz) spectra were recorded on a Bruker spectrometer. For ${ }^{13} \mathrm{C}$ NMR proton decoupling was used. Elemental analyses were performed at the Universidade de São Paulo, Brazil.

\section{Reagents}

All chemicals were reagent grade and were used without further purification, except for the reagents used in cytotoxic activities which were filtered $(0.2 \mu \mathrm{m})$.

\section{Synthesis of $N$-alkyl diamines}

The general procedure for preparation of the $N$-alkyl diamines ( $N$-octyl-1,2-ethanediamine, $N$-decyl-1,2ethanediamine, $N$-dodecyl-1,2-ethanediamine and $\mathrm{N}$-tetradecyl-1,2-ethanediamine) is analogous to the one previously described by our group for the $N$-alkyl diamines derived from propanediamine. ${ }^{13}$

\section{Synthesis of chloride complexes 1-4 (Scheme 1)}

To a solution of $\mathrm{K}_{2} \mathrm{PtCl}_{4}(0.415 \mathrm{~g}, 1 \mathrm{mmol})$ in water $(5 \mathrm{~mL})$, the appropriate diamine $(1 \mathrm{mmol})$ dissolved in water/ methanol $(5 \mathrm{~mL})$ was slowly added during $4 \mathrm{~h}$. After stirring for $24 \mathrm{~h}$ at room temperature, the pallid yellow solid formed was filtered off, washed with water, methanol and dried.

Yields: (1) $0.368 \mathrm{~g}$ (84\%), (2) $0.372 \mathrm{~g}(80 \%)$, (3) $0.405 \mathrm{~g}$ (82\%), (4) 0.421g (80\%). Anal. Calc. for $\mathrm{C}_{10} \mathrm{H}_{24} \mathrm{Cl}_{2} \mathrm{~N}_{2} \mathrm{Pt}$ (Compound 1): C, 27.40; H, 5.52; N, 6.39\%. Found: C, 27.76; H, 5.34; N, 6.19\%. $\mathrm{C}_{12} \mathrm{H}_{28} \mathrm{Cl}_{2} \mathrm{~N}_{2} \mathrm{Pt}$ (Compound 2): C, 30.91; H, 6.05; N, 6.01\%. Found: C, 30.70; H, 5.85; N, $6.02 \% . \mathrm{C}_{14} \mathrm{H}_{3} \mathrm{Cl}_{22} \mathrm{~N}_{2} \mathrm{Pt}$ (Compound 3): C, 34.01; H, 6.52; N, 5.67\%. Found: $\mathrm{C}, 34.61 ; \mathrm{H}, 6.45 ; \mathrm{N}, 5.78 \% . \mathrm{C}_{16} \mathrm{H}_{36} \mathrm{Cl}_{2} \mathrm{~N}_{2} \mathrm{Pt}$ (Compound 4): C, 36.78; H, 6.95; N, 5.36\%. Found: C, $37.65 ; \mathrm{H}, 6.84 ; \mathrm{N}, 5.51 \%$.

\section{Synthesis of oxalato complexes 5-8 (Scheme 1)}

To the chloride complexes $(1 \mathrm{mmol})$ in acetone $(10 \mathrm{~mL})$, $\mathrm{AgNO}_{3}(2.2 \mathrm{mmol})$ was added. After stirring for $24 \mathrm{~h}$ at $60^{\circ} \mathrm{C}$, the white solid formed $(\mathrm{AgCl})$ was filtered off. The filtrate was concentrated to dryness in a rotaevaporator and the yellow solid was dissolved in acetone and filtered to eliminate any excess of $\mathrm{AgNO}_{3} . \mathrm{Na}_{2} \mathrm{C}_{2} \mathrm{O}_{4}(0.303 \mathrm{~g} ; 1 \mathrm{mmol})$ in water $(100 \mathrm{~mL})$ was added to the filtrate. After stirring for $24 \mathrm{~h}$ at $50^{\circ} \mathrm{C}$, a beige precipitate was formed. The products were isolated by filtration, washed with water, methanol and dried. Yields: (5) $0.239 \mathrm{~g} \mathrm{(53 \% ),} \mathrm{(6)} 0.418 \mathrm{~g} \mathrm{(86 \% ),} \mathrm{(7)} 0.430 \mathrm{~g}$ (84\%), (8) $0.515 \mathrm{~g}(95 \%)$. Anal. Calc. for $\mathrm{C}_{12} \mathrm{H}_{24} \mathrm{~N}_{2} \mathrm{O}_{4} \mathrm{Pt}$ (Compound 5): C, 31.65; H, 5.31; N, 6.15\%. Found: C, 30.47; H, 4.99; N, 6.37\%. $\mathrm{C}_{14} \mathrm{H}_{28} \mathrm{~N}_{2} \mathrm{O}_{4} \mathrm{Pt}$ (Compound 6): C, 34.78; H, 5.84; N, 5.79\%. Found: C, 34.71; H, 5.84; N, 5.93\%. $\mathrm{C}_{16} \mathrm{H}_{32} \mathrm{~N}_{2} \mathrm{O}_{4} \mathrm{Pt}$ (Compound 7): C, 37.57; H, 6.31; N, 5.48\%. Found: C, 35.55; H, 5.86; N, 5.14\%. $\mathrm{C}_{18} \mathrm{H}_{36} \mathrm{~N}_{2} \mathrm{O}_{4} \mathrm{Pt}$ (Coumpound 8): C, 40.07; H, 6.72; N, 5.19\%. Found: C, 39.95; H, 6.71; N, 5.29\%.

\section{Partition coefficients}

Partition coefficients for the platinum complexes were determined in duplicate in an $n$-octanol/water system..$^{25}$ Each complex was dissolved in $n$-octanol at $20 \mu \mathrm{mol} \mathrm{L}^{-1}$ and, subsequently, an equal volume of water was added. The mixtures were shaken mechanically for $24 \mathrm{~h}$ to ensure the distribution between the two solvent phases. The platinum concentration was determined in both phases by GFAAS in a THGA-Perkin Elmer spectrophotometer equipped with a graphite tube atomizer and an Analyst 600 auto sampler. Results are expressed as logarithm of $P(\log P)$, where $P$ is the total platinum concentration in $n$-octanol divided by the total platinum concentration in the aqueous layer. ${ }^{26}$ 


\section{Cell lines and cultures}

The cytotoxic activities were investigated against the following tumor cell lines: $\mathrm{A}_{549}$ human non-small cell lung carcinoma, B16-F1 mouse non-metastatic cell skin melanoma, B16-F10 mouse metastatic cell skin melanoma, MDA-MB-231 human cell breast adenocarcinoma, and non-tumor cell lines such as BHK-21 hamster cell kidney and $\mathrm{CHO}$ hamster cell ovary.

These cells were obtained from the Ludwig Institute of Cancer Research, São Paulo-Brazil (B16-F1, B16-F10 and MDA-MB-231), from the cell bank of the Universidade Federal do Rio de Janeiro, Rio de Janeiro-Brazil $\left(\mathrm{A}_{549}\right)$ and from the Centro Panamericano de Febre Aftosa, Rio de Janeiro-Brazil (BHK-21 and CHO). They were propagated in cell culture medium RPMI $1640 \mathrm{pH}$ 7.4, supplemented with 10\% heat-inactivated Fetal Bovine Serum (FBS), Hepes (4-(2-hydroxyethyl)-1-piperazineethanesulfonic acid, $\left.4.0 \mathrm{mmol} \mathrm{L}^{-1}\right), \mathrm{NaHCO}_{3}\left(14.0 \mathrm{mmol} \mathrm{L}^{-1}\right)$, ampicillin $\left(0.27 \mathrm{mmol} \mathrm{L}^{-1}\right)$ and streptomycin $\left(0.06 \mathrm{mmol} \mathrm{L}^{-1}\right)$.

Cells were harvested by trypsinization, seeded in $100 \mu \mathrm{L}$ of cell culture medium at defined densities (ranging from $0.5 \times 10^{3}$ to $2 \times 10^{3}$ living cells per well, depending on the cell line) into 96 -well tissue culture plates and incubated at $37{ }^{\circ} \mathrm{C}$ in a humidified atmosphere containing $5 \% \mathrm{CO}_{2}$ for $24 \mathrm{~h}$. Stock solutions of the test substances in dmso were serially diluted in cell culture medium. $100 \mu \mathrm{L}$ of these four dilutions were added to the cells in six wells each. For a negative control, $100 \mu \mathrm{L}$ of cell culture medium were added to twelve wells (100\% value). After drug exposure for $120 \mathrm{~h}$ at $37{ }^{\circ} \mathrm{C}$ and $5 \% \mathrm{CO}_{2}$, the cells were incubated with MTT (3-(4,5-dimethyl-2-thiazolyl)-2,5-diphenyl- $2 \mathrm{H}$ tetrazolium bromide, Sigma-Aldrich) $0.01 \mathrm{~mol} \mathrm{~L}^{-1}$ in water solution (added in aliquots of $10 \mu \mathrm{L}$ per well) for $4 \mathrm{~h}$ at $37^{\circ} \mathrm{C}$ and $5 \% \mathrm{CO}_{2}$. MTT is metabolized by living cells resulting in a violet complex which was solubilized in $100 \mu \mathrm{L}$ of dmso and determined by the colorimetric method using an ELISA reader at $570 \mathrm{~nm}$. Positive controls, such as cisplatin and carboplatin, were also used against these cell lines.

The raw data were normalized to the untreated control cells and related to the metabolic activity of the viable treated cells. The $\mathrm{IC}_{50}$ values, concentration required to inhibit $50 \%$ of cell growth, were calculated by fourparameter nonlinear regression using GraphPad Prism 5.0 software (San Diego, USA). ${ }^{27}$

\section{Conclusions}

Novel platinum(II) complexes of long chain aliphatic diamine ligands with oxalato as the leaving group have been prepared and characterized. The effect of these compounds on tumor and non-tumor cell lines has been investigated. The chloride complexes are more cytotoxic than the corresponding oxalato complexes, probably due to the faster rate of hydrolysis of the formers. Another possibility could be related to the difference in the rate of cellular uptake. The relationship between cytotoxicity and carbon chain length was confirmed independently of the leaving group used.

\section{Acknowledgments}

To FAPEMIG and CNPq for financial support and fellowships.

\section{References}

1. Natile, G.; Coluccia, M.; Coord. Chem. Rev. 2001, 216, 383.

2. Pratt, W. B.; Ruddon, R. W.; Ensminger, W. D.; Maybaum, J.; The Anticancer Drugs, Oxford University Press: New York, 1994, pp. 133-139.

3. Hambley, T. W.; Coord. Chem. Rev. 1997, 166, 181.

4. Sykes, A. G.; Platinum Met. Rev. 1988, 32, 170.

5. Pasini, A.; Zunino, F.; Angew Chem., Int. Ed. 1987, 26, 615.

6. Farrell, N.; Qu, Y.; Hacker, M. P.; J. Med. Chem. 1990, 33, 2179.

7. Summa, N.; Soldatovic, T.; Danlenburg, L.; Bugarcic, Z. D.; Eldik, R. V.; J. Biol. Inorg. Chem. 2007, 12, 461.

8. Bolelikas, T.; Vougiouka, M.; Oncol. Reports 2003, 10, 1663.

9. Mathé, G.; Kidani, Y.; Sekiguichi, M.; Eriguchi, M.; Fredj, G.; Peytavin, G.; Misset, J. L.; Brienza, S.; de Vassals, F.; Chenu, E.; Bourut, C.; Biomed. Pharmacother. 1989, 43, 237.

10. Lippard, S. J.; Wang, D.; Nat. Rev. Drug Discov. 2005, 4, 307.

11. Fontes, A. P. S.; de Almeida, S. G.; Nader, L. A.; Quim. Nova 1997, 20, 398.

12. Schreier, S.; Malheiros, S. V. P.; de Paula, E.; Biochim. Biophys. Acta, Biomembr. 2000, 1508, 210.

13. Silva, H.; Barra, C. V.; da Costa, C. F.; de Almeida, M. V.; César, E. T.; Silveira, J. N.; Garnier-Suillerot, A.; de Paula, F. C. S.; Pereira-Maia, E. C.; Fontes, A. P. S.; J. Inorg. Biochem. 2008, $102,767$.

14. Miller, B.; Wild, S.; Zorbas, H.; Beck, W.; Inorg. Chim. Acta 1999, 290, 237.

15. Dhara, S. C.; Indian J. Chem. 1970, 8, 193.

16. de Almeida, M. V.; Chaves, J. D. S.; Fontes, A. P. S.; César, E. T.; Gielen, M.; J. Braz. Chem. Soc. 2006, 17, 1266.

17. de Almeida, M. V.; César, E. T.; Felício, E. C. A.; Fontes, A. P. S.; J. Braz. Chem. Soc. 2000, 11, 154.

18. Fiebig, H. H.; Heuss, H.; Vonpawel, L.; Gatzemeier, U.; Manegold, C.; Edler, L.; Berdel, W.; Onkologie 1996, 19, 328.

19. Monti, E.; Gariboldi, M.; Maiocchi, A.; Marengo, E.; Cassino, C.; Gabano, E.; Osella, D.; J. Med. Chem. 2005, 48, 857. 
20. Platts, J. A.; Oldfield, S. P.; Reif, M. M.; Palmucci, A.; Gabano, E.; Osella, D.; J. Inorg. Biochem. 2006, 100, 1199.

21. Oldfield, S. P.; Hall, M. D.; Platts, J. A.; J. Med. Chem. 2007, $50,5227$.

22. Pereira-Maia, E. C.; Garnier-Suillerot, A.; JBIC, J. Biol. Inorg. Chem. 2003, 8, 626 .

23. Ma, E. S. F.; Bates, W. D.; Edmunds, A.; Kelland, L. R.; Fojo, T.; Farrell, N.; J. Med. Chem. 2005, 48, 5651.

24. Canovese, L.; Cattalini, L.; Chessa, G.; J. Chem. Soc., Dalton Trans. 1988, 8, 2135.
25. Screnci, D.; McKeage, M. J.; Galettis, P.; Hambley, T. W.; Palmer, B. D.; Baguley, B. C.; Br. J. Cancer 2000, 82, 966.

26. Guerra, W.; Silva, I. R.; Azevedo, E. A.; Monteiro, A. R. S.; Bucciarelli-Rodriguez, M.; Chartone-Souza, E.; Silveira, J. N.; Fontes, A. P. S.; Pereira-Maia, E. C.; J. Braz. Chem. Soc. 2006, 17, 1627.

27. Garmann, D.; Warnecke, A.; Kalayda, G. V.; Kratz, F.; Jaehde, U.; J. Controlled Release 2008, 131, 100.

Submitted: October 15, 2009 Published online: July 13, 2010 